\title{
Correction to: Community organizing in Sunset Park on the eve of the 2016 election
}

\section{Luis Guzmán Valerio ${ }^{1}$}

Published online: 22 August 2019

(C) Springer Nature Limited 2019

\section{Correction to: Latino Studies https://doi.org/10.1057/s41276-019-00187-x}

Unfortunately "meter" was replaced by "miles" in the whole article. We apologize for this mistake.

Publisher's Note Springer Nature remains neutral with regard to jurisdictional claims in published maps and institutional affiliations.

The original article can be found online at https://doi.org/10.1057/s41276-019-00187-x.

\section{Luis Guzmán Valerio}

luisalejandroguzman@hotmail.com

1 Northbrook, Illinois, USA 